\title{
Synthesis, Characterization and Biological Approach of N'-(3-(Hydroxy Imino) Butan-2-ylidene)-2-Oxo-2H-Chromene-3-Carbohydrazide Complexes
}

\author{
Zaky RR*, Ibrahim KM and Abouelala EE \\ Department of Chemistry, Mansoura University, Mansoura, Egypt
}

\begin{abstract}
A series of metal complexes of $\mathrm{Cu}(\Pi), \mathrm{Co}(\Pi), \mathrm{Ni}(\Pi), \mathrm{Cd}(\Pi)$ and $\mathrm{Hg}(\Pi)$ complexes with N'-(3-(hydroxyimino) butan2-ylidene)-2-oxo-2H-chromene-3-carbohydrazide $\left(\mathrm{H}_{2} \mathrm{~L}\right)$ were prepared. The structures illuminated by elemental and thermal analysis, besides spectroscopic methods (IR, ${ }^{1} \mathrm{H}$ NMR, and UV-visible, MS) and physical measurements (molar conductance and magnetic susceptibility). In addition, DFT method used to approve the geometry of solid complexes. From conductmetric measurements, all complexes were non-electrolytic and formed by molar ratio 1:2 expect $\mathrm{Hg}(\Pi)$ complexes by 1:1. Moreover, the biological activity (Antibacterial, antifungal and DNA binding) performed for all prepared compounds.
\end{abstract}

Keywords: Coumarin compounds; Spectroscopy; DFT; Biological activity

\section{Introduction}

Coumarin family considered an essential heterocyclic compounds which belong to benzopyrones family that contains of phenyl ring fused with a pyrone ring [1,2]. Coumarin classified into six groups count on chemical structure of compounds and these group are simple (coumarins, bi coumarins, phenyl coumarins, pyrano coumarins, furano coumarins and dihydrofurano coumarins) [3] Coumarin mainly existed in plant kingdom such as (leaves, roots, stems and fruits). Besides, they found in different oils as "lavender oil, cinnamon bark, oil and cassia oil" [4]. Moreover, coumarin derivatives have changed uses such as "optical brightening agents, laser dyes, cosmetic industry agrochemical industries and food additives" [57]. Furthermore, Coumarin derivatives have important biological activity as antibacterial, antifungal, anti-oxidant, anti-allergic, antiinflammatory, anti-thrombotic, hepatoprotective, anti-viral, anticarcinogenic activities [8-10]. So, this study involved the biological estimation of $N^{\prime}$-(3-(hydroxyimino) butan-2-ylidene)-2-oxo- $2 \mathrm{H}$ chromene-3-carbohydrazide $\left(\mathrm{H}_{2} \mathrm{~L}\right)$ and its metal complexes.

\section{Experimental}

\section{Materials and reagents}

All materials and reagents used obtained since viable sources such as (Aldrich, Fluka, or Merck). They involved (a) 2-oxo-2H-chromene3 -carbohydrazide and diacetyl monoxime as (organic substances), (b) $\left[\mathrm{Cu}\left(\mathrm{CH}_{3} \mathrm{COO}\right)_{2}\right] . \mathrm{H}_{2} \mathrm{O},\left[\mathrm{Ni}\left(\mathrm{CH}_{3} \mathrm{COO}\right)_{2}\right] .4 \mathrm{H}_{2} \mathrm{O} ;\left[\mathrm{Co}\left(\mathrm{CH}_{3} \mathrm{COO}\right)_{2}\right] \cdot 4 \mathrm{H}_{2} \mathrm{O}$; $\mathrm{HgCl}_{2}$ and $\mathrm{CdSO}_{4}$ as (metal salts), and (c) absolute ethanol, dimethylformamide, dimethyl sulfoxide and diethyl ether as solvents.

\section{Instrumentations}

IR spectrum noted on" Mattson 5000 FTIR Spectrophotometer" in the series (4000-400) $\mathrm{cm}^{-1}$ in "KBr" disk. The electronic spectra of the complexes verified in "DMSO" solution using a "Shimadzu UV 240 (P/N 204-58000) spectrophotometer"(USA) in the scale (200-900) $\mathrm{nm}$. "Magnetic moment values" were calculated at room temperature $\left(25 \pm 1^{\circ} \mathrm{C}\right)$ using a "Johnson Matthey magnetic susceptibility balance" using $\mathrm{Hg}\left[\mathrm{Co}(\mathrm{SCN})_{4}\right]$ as calibrant ${ }^{1} \mathrm{H}$ NMR spectra of the ligand, diamagnetic complexes were detailed in "DMSO" on an "EM-390 (200 $\mathrm{MHz}$ ) spectrometer". The percentage of $\mathrm{C}$ and $\mathrm{H}$ determined by using "Perkine Elmer 2400 Series II" in the Micro Analytical Center, Cairo University. Molar conductance of complexes measured via organizing $\left(10^{-3} \mathrm{M}\right)$ solutions of complexes in DMF at $\left(25^{\circ} \mathrm{C}\right)$ and dignified on an "YSI Model32" conductivity bridge. The specific conductance values were detailed by conductivity bridge "HANNA, H1 8819N" with a cell constant equivalent to (1) $\mathrm{cm}^{-1}$. The conductometer connected with ultra-thermostat of the type "Kottermann 4130" too a digital thermometer.

\section{Synthesis of $\mathrm{H}_{2} \mathrm{~L}$}

By mixing between 2-oxo-2H-chromene-3-carbohydrazide $(0.01$ mole, $2.04 \mathrm{~g})$ and diacetyl monoxime $(0.01$ mole, $1.01 \mathrm{~g})$ in $50 \mathrm{ml}$ ethanol in presence of 3 drops of (GAA) (Figure 1). By refluxing 3 hours. After that, filter the precipitate and recrystallized from absolute ethanol. The analytical and physical properties collected in Table 1.

\section{Synthesis of metal complexes}

The solid complexes performed via count identical amount of $\mathrm{H}_{2} \mathrm{~L}$ with hot $\left(\mathrm{C}_{2} \mathrm{H}_{5} \mathrm{OH}\right.$ and/or $\left.\mathrm{H}_{2} \mathrm{O}\right)$ of $\mathrm{HgCl}_{2} ; \mathrm{CdSO}_{4}$ and $\mathrm{Ni}(\mathrm{II}) ; \mathrm{Co}(\mathrm{II}) ; \mathrm{Cu}(\mathrm{II})$ as acetate salt. The mix refluxed on a water bath for (3 hours). The formed precipitate filtered off, washed with hot absolute ethyl alcohol.

\section{Molecular modelling}

Using Materials Studio package to calculated cluster calculations through DMOL3 [11]. The DFT method used to analyze of geometry of the sequestered complexes via "GAUSSIAN 09" program set [12]. The "DNP" source groups are of equivalent course to "6-31G" Gaussian basis groups [13]. The Gaussian basis groups are fewer accurate than DNP basis sets of the same size [14]. The brilliant exchange-correlation functional considered constructed on the (GGA) and (RPBE) functional [15].

*Corresponding author: Zaky RR, Department of Chemistry, Mansoura University, Mansoura, Egypt, Tel: +201097799452; E-mail: rania.zaky@yahoo.com

Received October 21, 2016; Accepted December 05, 2016; Published December 10, 2016

Citation: Zaky RR, Ibrahim KM, Abouelala EE (2016) Synthesis, Characterization and Biological Approach of $\mathrm{N}^{\prime}$-(3-(Hydroxy Imino) Butan-2-ylidene)-2-Oxo-2HChromene-3-Carbohydrazide Complexes. Mod Chem appl 5: 198. doi: 10.4172/23296798.1000198

Copyright: $\odot 2016$ Zaky RR, et al. This is an open-access article distributed under the terms of the Creative Commons Attribution License, which permits unrestricted use, distribution, and reproduction in any medium, provided the original author and source are credited. 


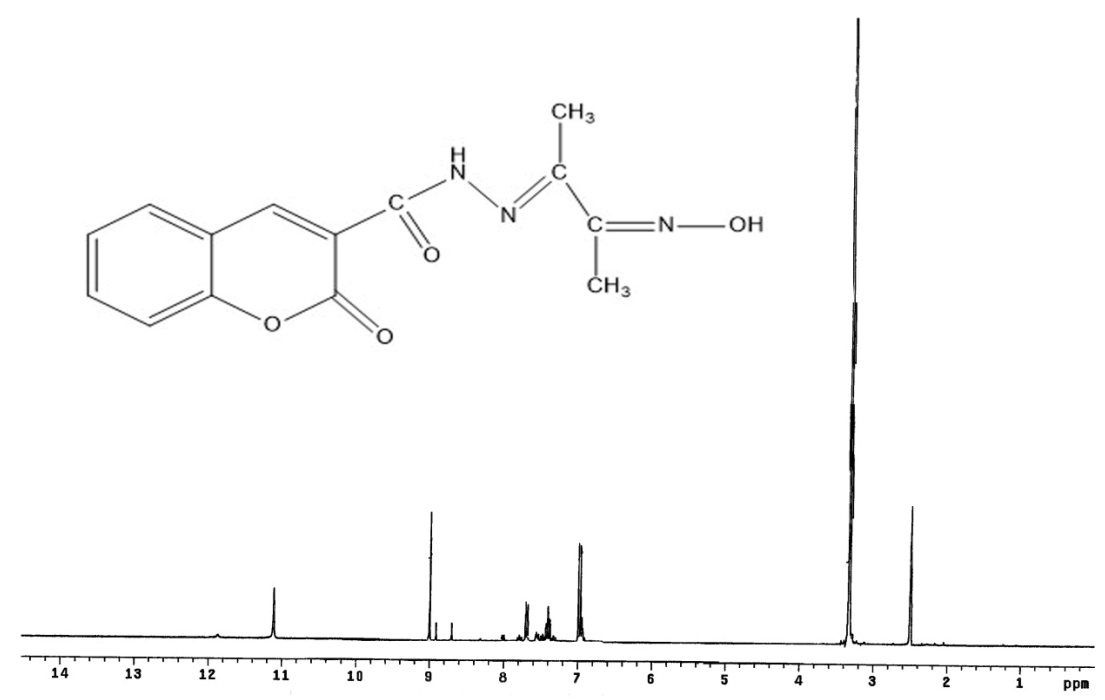

Figure 1: HNMR spectrum of N'-(3-(hydroxyimino) butan-2-ylidene)-2-oxo-2H-chromene-3-carbohydrazide in DMSO.

\begin{tabular}{|c|c|c|c|c|c|c|c|c|c|c|}
\hline \multirow{2}{*}{ No } & \multirow{2}{*}{ Compound } & \multirow{2}{*}{ formula } & \multirow{2}{*}{ MWt } & \multirow{2}{*}{ Yield } & \multirow{2}{*}{ colour } & \multirow{2}{*}{ m.p } & \multicolumn{4}{|c|}{ Found (Calculated) } \\
\hline & & & & & & & C & $\mathbf{H}$ & M & $\mathbf{x}$ \\
\hline 1 & $\mathrm{H}_{2} \mathrm{~L}$ & $\mathrm{C}_{14} \mathrm{H}_{13} \mathrm{~N}_{3} \mathrm{O}_{4}$ & 287.29 & 80 & Pale yellow & 290 & $\begin{array}{l}(58.53) \\
(59.00)\end{array}$ & $\begin{array}{l}(4.56) \\
(4.00)\end{array}$ & - & $\begin{array}{l}- \\
-\end{array}$ \\
\hline 2 & {$\left[\mathrm{Cu}\left(\mathrm{H}_{2} \mathrm{~L}\right)_{2}(\mathrm{OAc})_{2}\right]$} & $\mathrm{CuC}_{32} \mathrm{H}_{32} \mathrm{O}_{12} \mathrm{~N}_{6}$ & 756.22 & 80 & Green & $>300$ & $\begin{array}{l}(29.15) \\
(28.65)\end{array}$ & $\begin{array}{l}(4.26) \\
(4.41)\end{array}$ & $\begin{array}{l}(8.40) \\
(8.91)\end{array}$ & \\
\hline 3 & {$\left[\mathrm{Cd}\left(\mathrm{H}_{2} \mathrm{~L}\right)_{2}\left(\mathrm{SO}_{4}\right)\right]$} & $\mathrm{CdC}_{28} \mathrm{H}_{26} \mathrm{~N}_{6} \mathrm{O}_{12} \mathrm{~S}$ & 783.05 & 70 & yellow & $>300$ & $\begin{array}{l}(42.95) \\
(42.50)\end{array}$ & $\begin{array}{l}(3.35 .) \\
(3.00)\end{array}$ & $\begin{array}{l}(14.35) \\
(13.80)\end{array}$ & $\begin{array}{l}(12.27) \\
(11.80)\end{array}$ \\
\hline 4 & {$\left[\mathrm{Ni}\left(\mathrm{H}_{2} \mathrm{~L}\right)_{2}(\mathrm{OAc})_{2}\right]$} & $\mathrm{NiC}_{32} \mathrm{H}_{32} \mathrm{O}_{12} \mathrm{~N}_{6}$ & 751.36 & 80 & Reddish brown & $>300$ & $\begin{array}{l}(51.14) \\
(50.70)\end{array}$ & $\begin{array}{l}(4.29) \\
(4.80)\end{array}$ & $\begin{array}{l}(7.84) \\
(8.00)\end{array}$ & - \\
\hline 5 & {$\left[\mathrm{Co}\left(\mathrm{H}_{2} \mathrm{~L}\right)_{2}(\mathrm{OAc})_{2}\right]$} & $\mathrm{CoC}_{32} \mathrm{H}_{32} \mathrm{O}_{12} \mathrm{~N}^{6}$ & 751.603 & 75 & Reddishbrown & $>300$ & $\begin{array}{l}(51.14) \\
(50.80)\end{array}$ & $\begin{array}{l}(4.29) \\
(3.80)\end{array}$ & $\begin{array}{l}(7.84) \\
(8.00)\end{array}$ & - \\
\hline 6 & {$\left[\mathrm{Hg}\left(\mathrm{H}_{2} \mathrm{~L}\right)(\mathrm{Cl})_{2}\left(\mathrm{H}_{2} \mathrm{O}\right)\right]$} & $\mathrm{HgC}_{14} \mathrm{H}_{15} \mathrm{O}_{5} \mathrm{~N}_{3} \mathrm{Cl}_{2}$ & 576.91 & 80 & brown & $>300$ & $\begin{array}{l}(29.15) \\
(28.65)\end{array}$ & $\begin{array}{l}(2.62) \\
(3.12)\end{array}$ & $\begin{array}{l}(34.77) \\
(34.20)\end{array}$ & $\begin{array}{c}(12.31) \\
(12.6)\end{array}$ \\
\hline
\end{tabular}

$\mathrm{X}=\mathrm{Cl}^{-}$

Table 1: Elemental analysis and physical data of $\mathrm{H}_{2} \mathrm{~L}$ and its metal complexes.

Antibacterial and antifungal activities in terms of minimum inhibitory concentration

Using disc diffusion technique to govern MIC of the isolatedcompounds [16]. These involved (+ve) gram "Staphylococcus aureus, Bacillus subtilis". However, (-ve) gram "Escherichia coli, Pseudomonas aeuroginosa" as bacteria, (Candida albinos, Aspergillus flavus) as fungi. By ampicillin $(1000 \mu \mathrm{g} / \mathrm{ml})$ as standard antibacterial, then Clotrimazole $(1000 \mu \mathrm{g} / \mathrm{ml})$ as standard antifungal. A $(1000 \mu \mathrm{g} /$ $\mathrm{ml}$ ) standard solution of the studied compounds in DMSO was set and immunized media parallel running to the examination compounds at the same condition. The microorganism suspensions at (10 CFU/ $\mathrm{ml}$ - colony forming unit/ml) concentration were immunized to the agreeing wells. Raising plate's temperature to $\left(36^{\circ} \mathrm{C}\right)$ for one day. Finally, MIC values recorded as the lowest concentration of substances, which have no visible turbidity.

\section{Colorimetric assay for compounds that bind DNA}

$(20 \mathrm{mg})$ DNA methyl green suspended in $(100 \mathrm{ml})$ of $(0.05 \mathrm{M})$ Tris- $\mathrm{HCl}$ as buffer $(\mathrm{pH} 7.5)$ containing $(7.5 \mathrm{mM}) \mathrm{MgSO}_{4}$; this mixture was stirred $(24 \mathrm{~h})$ at $\left(37^{\circ} \mathrm{C}\right)$. A series of $(10,100,1000 \mathrm{mg})$ were dissolved isolated compound in ethanol in Ependoff tubes, solvent was indifferent below vacuum, then $(200 \mu \mathrm{l})$ of (DNA/methyl green) solution were added to all tube. Samples raised in darkness at ambient temperature. After one day, determine the absorbance at (642.5-645) $\mathrm{nm}$. The modification data for primary absorbance and normalized as the percentage of the untreated standard [17].

\section{Conductance measurement}

The conductance was measured to $(\mathrm{Cu}, \mathrm{Ni}$ and $\mathrm{Co})$ as metal salts in mixture solvent ( $5 \% \mathrm{DMF} / \mathrm{Methanol})$. The conduct metric titrations were measured $\left(1 \times 10^{-3}\right) \mathrm{M}$ of $\mathrm{H}_{2} \mathrm{~L}$ ligand as original concentration from each metal salt solutions and using $\left(1 \times 10^{-4}\right) \mathrm{M}$ of these metal salt. (20) $\mathrm{ml}$ of salt in mixed solvent of (5\% DMF-methanol) was full and titrated against small amount of ligand with $(0.2) \mathrm{ml}$ breaks were done as well as the $\left(\mathrm{k}_{\mathrm{s}}\right)$ specific conductance was considered. The temperature, in all quantities reached, adjusted at room temperature. The conduct metric titrations attained due to variance of metal salt concretion as titrated solutions with the ligand as a titrant.

\section{Results and Discussion}

The types of metal complexes were obtained from the reaction of hydrazone with " $\mathrm{Cu}(\mathrm{II}), \mathrm{Cd}(\mathrm{II}), \mathrm{Ni}(\mathrm{II}), \mathrm{Co}(\mathrm{II})$, and $\mathrm{Hg}(\mathrm{II})$ " metal ions everywhere the ligand behaviour as (neutral mono, bi, and tridentate) manner. The molar conductivities of all solid complexes shown complexes were non-electrolysis.

\section{IR and ${ }^{1} \mathrm{H}$ NMR spectra}

The IR spectra displayed that a significant $\mathrm{H}_{2} \mathrm{~L}$ (Table 2) bands at 
$\left(3447,3220,1698,1665,1611\right.$ and 1566) $\mathrm{cm}^{-1}$ were assigned to $\mathrm{v}(\mathrm{OH})$ , $\mathrm{v}(\mathrm{NH}), \mathrm{v}(\mathrm{C}=\mathrm{O})_{1}, \mathrm{v}(\mathrm{C}=\mathrm{O})_{2}, \mathrm{v}(\mathrm{C}=\mathrm{N})_{\text {azo }}$ and $\mathrm{v}(\mathrm{C}=\mathrm{N})$, respectively [18-23]. In addition, ${ }^{1} \mathrm{HNMR}$ spectrum of $\mathrm{H}_{2} \mathrm{~L}$ (Figure 2) was showed four signals at $(11.11 ; 9.00 ; 3.30$ and 2.49$) \mathrm{ppm}$ assignable to the protons of $(\mathrm{OH})_{\text {oxime }} ;(\mathrm{NH}) ;\left(\left(-\mathrm{C}\left(\mathrm{CH}_{3}\right)=\mathrm{N}(\mathrm{OH})-\right)\right.$ and $\left(-\mathrm{C}\left(\mathrm{CH}_{3}\right)=\mathrm{N}-\right.$ $\mathrm{NH})$. The signals of aromatic protons detected in (6.93-7.71) ppm. The IR spectrum of $\left[\mathrm{Cu}\left(\mathrm{H}_{2} \mathrm{~L}\right)_{2}(\mathrm{OAc})_{2}\right]$ complex indicated that the $\mathrm{H}_{2} \mathrm{~L}$ acted as a neutral monodentate ligand coordinating through $\mathrm{v}(\mathrm{C}=\mathrm{O})_{2}$. The coordination maintained by: (a) Band of $\mathrm{v}(\mathrm{C}=\mathrm{O})_{2}$ move to lower wave number at $(1650) \mathrm{cm}^{-1}$; (b) The appearance of new band at 530 $\mathrm{cm}^{-1}$ that may be recognized to $\mathrm{v}(\mathrm{Cu}-\mathrm{O})$ and (c) the appearance of $\mathrm{v}(\mathrm{C}=\mathrm{O})_{2}, \mathrm{v}(\mathrm{C}=\mathrm{N})_{\text {azo }}$ and $\mathrm{v}(\mathrm{C}=\mathrm{N})$ nearly at the same position. Also, in $\left[\mathrm{Cd}\left(\mathrm{H}_{2} \mathrm{~L}\right)_{2}\left(\mathrm{SO}_{4}\right)\right]$ complexes acted as neutral bidentate ligand coordinating via $\mathrm{v}(\mathrm{C}=\mathrm{O})_{2}, \mathrm{v}(\mathrm{C}=\mathrm{N})_{\text {azo }}$. The complexation confirmed via: (a) the modification of $\mathrm{v}(\mathrm{C}=\mathrm{O})_{2}$ and $\mathrm{v}(\mathrm{C}=\mathrm{N})_{\text {azo }}$ to lower wave number at (1654 and 1545) $\mathrm{cm}^{-1}$; (b) the appearance of new bands at $(568$ and 457$) \mathrm{cm}^{-1}$ which sign to $\mathrm{v}(\mathrm{Cd}-\mathrm{O})$ and $\mathrm{v}(\mathrm{Cd}-\mathrm{N})$; (c) the ${ }^{1} \mathrm{H}$ NMR spectrum proposed that $(\mathrm{NH}$ and $\mathrm{OH})$ not shared in complexation. But, in $\left[\mathrm{Ni}\left(\mathrm{H}_{2} \mathrm{~L}\right)_{2}(\mathrm{OAc})_{2}\right]$ and $\left[\mathrm{Co}\left(\mathrm{H}_{2} \mathrm{~L}\right)_{2}(\mathrm{OAc})_{2}\right]$ complexes acted as neutral bidentate ligand coordinating in $\mathrm{v}(\mathrm{C}=\mathrm{O})_{1}$ and $\mathrm{v}(\mathrm{C}=\mathrm{O})_{\text {azo }}$. The chelation was supported by: (a) the shift of $\mathrm{v}(\mathrm{C}=\mathrm{O})_{1}$ and $\mathrm{v}(\mathrm{C}=\mathrm{O})_{2}$ to lower wave number $(1670$ and 1650$) \mathrm{cm}^{-1}$. (b) The presence of new bands at $(495) \mathrm{cm}^{-1}$ which attributed to $\mathrm{v}(\mathrm{M}$ $\mathrm{O})$. Finally, the IR spectra of $\left[\mathrm{Hg}\left(\mathrm{H}_{2} \mathrm{~L}\right)\left(\mathrm{H}_{2} \mathrm{O}\right)(\mathrm{Cl})_{2}\right]$ complex acted as neutral tridentate coordinating via $\mathrm{v}(\mathrm{C}=\mathrm{O})_{2}, \mathrm{v}(\mathrm{C}=\mathrm{N})_{\text {azo }}$ and $\mathrm{v}(\mathrm{NH})$. The chelation maintained by: (a) the shift of $\mathrm{v}(\mathrm{C}=\mathrm{O})_{2}, \mathrm{v}(\mathrm{C}=\mathrm{N})$ and $\mathrm{v}(\mathrm{NH})$ to lower wavenumbers $(1652,1546$ and 3192$) \mathrm{cm}^{-1}$. (b) Other evidence presence of new bands at ( 546 and 422$) \mathrm{cm}^{-1}$ which could be official to $\mathrm{u}(\mathrm{Hg}-\mathrm{O})$ andu $(\mathrm{Hg}-\mathrm{N})$.

\section{Electronic spectra and magnetic moment measurements}

The electronic spectrum of $\left[\mathrm{Cu}\left(\mathrm{H}_{2} \mathrm{~L}\right)_{2}(\mathrm{OAc})_{2}\right]$ complex (Table 3) was showed abroad band at (16501) $\mathrm{cm}^{-1}$ with shoulder at (14925) $\mathrm{cm}^{-1}$ which may be allocated to $\left({ }^{2} \mathrm{~B}_{1 \mathrm{~g}} \rightarrow{ }^{2} \mathrm{E}_{\mathrm{g}}\right)$ and $\left({ }^{2} \mathrm{~B}_{1 \mathrm{~g}} \rightarrow{ }^{2} \mathrm{~A}_{1 \mathrm{~g}}\right)$ transition,

\begin{tabular}{|c|c|c|c|c|c|c|c|c|}
\hline $\mathbf{u}(\mathbf{M}-\mathbf{N})$ & $\mathbf{u}(\mathbf{M}-\mathbf{O})$ & $\mathbf{v}(\mathbf{C}=\mathbf{N})_{\mathbf{2}}$ & $\mathbf{0}(\mathbf{C}=\mathbf{N})_{\mathbf{1}}$ & $\mathbf{0}(\mathbf{C}=\mathbf{O})_{\mathbf{2}}$ & $\mathbf{v}(\mathbf{C}=\mathbf{O})_{\mathbf{1}}$ & $\mathbf{0}(\mathbf{N H})$ & $\mathbf{0}(\mathbf{O H})$ & Compound \\
\hline- & - & 1566 & 1611 & 1665 & 1698 & 3220 & 3447 & 1 \\
\hline- & 530 & 1568 & 1613 & 1650 & 1701 & 3220 & 3425 & 2 \\
\hline 457 & 568 & 1545 & 1611 & 1654 & 1710 & 3188 & 3448 & 3 \\
\hline- & 495 & 1613 & 1650 & 1650 & 1676 & 3220 & 3422 & 4 \\
\hline- & 495 & 1568 & 1614 & 1650 & 1670 & 3240 & 3422 & 5 \\
\hline 422 & 546 & 1546 & 1605 & 1652 & 1712 & 3192 & 3423 & $\mathbf{6}$ \\
\hline
\end{tabular}

Table 2: Most important IR spectral bands of $\mathrm{H}_{2} \mathrm{~L}$ and its metal complexes.

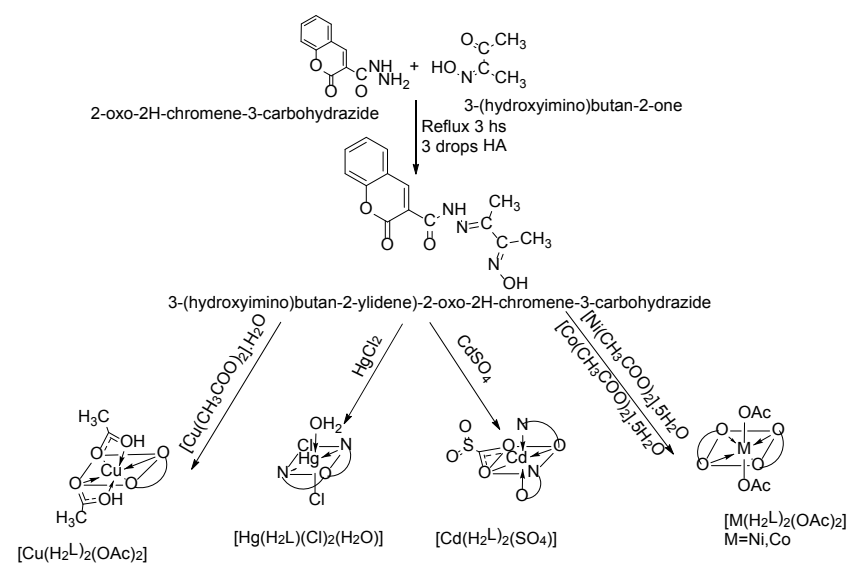

Figure 2: The outline synthesis of $\mathrm{H}_{2} \mathrm{~L}$ and its metal complexes. individually, in tetragonally distorted an octahedral configuration. The value of magnetic moment of $\mathrm{Cu}(\Pi)$ complex equal to $(2.1 \mathrm{BM})$ [24]. The electronic spectrum of $\left[\mathrm{Ni}\left(\mathrm{H}_{2} \mathrm{~L}\right)_{2}(\mathrm{OAc})_{2}\right]$ complex was displayed two bands at (17094 and 28571) $\mathrm{cm}^{-1}$ described to $\left({ }^{3} \mathrm{~A}_{2 \mathrm{~g}} \rightarrow\right.$ $\left.{ }^{3} \mathrm{~T}_{1 \mathrm{~g}}(\mathrm{~F})\right)$ besides $\left({ }^{3} \mathrm{~A}_{2} \mathrm{~g} \rightarrow{ }^{3} \mathrm{~T}_{1 \mathrm{~g}}(\mathrm{p})\right)$ transitions, in octahedral structure. Calculated value of (Dq, B, $\beta$ and $\left.\left(v_{2} / v_{1}\right)\right)$ values lie in the series told for an octahedral structure. In addition, the magnetic moments value (3.2 BM). The value of $v_{1}(9777.89) \mathrm{cm}^{-1}$ was calculated theoretically [24]. The electronic spectrum of $\left[\mathrm{Co}\left(\mathrm{H}_{2} \mathrm{~L}\right)_{2}(\mathrm{OAc})_{2}\right]$ complex showed two bands at (17857 and 23364) $\mathrm{cm}^{-1}$ attributed to $\left(\left({ }^{4} \mathrm{~T}_{1 \mathrm{~g}} \rightarrow{ }^{4} \mathrm{~A}_{2 \mathrm{~g}}(\mathrm{~F})\right.\right.$ also $\left({ }^{4} \mathrm{~T}_{1 \mathrm{~g}} \rightarrow{ }^{4} \mathrm{~T}_{1 \mathrm{~g}}(\mathrm{P})\right)$ transitions, individually, in an octahedral geometry. The calculated values of $\left(D_{q}, B, \beta\right.$ an $\left.\left(v_{2} / v_{1}\right)\right)$ are good agreement with those informed for octahedral $\mathrm{Co}$ (II) complexes. The point of $\mathrm{v}_{1}(8104) \mathrm{cm}^{-1}$ was intended theoretically. In addition, the magnetic moment value (5.1) BM was proof octahedral around Co (II).

\section{Geometry optimization with DFT method}

The structure of new compounds can be accepted in applying computational chemistry tools that is a potent protocol for construing their stabilities and calculated many structural parameters for hydrazone ligand (Table 4). DFT calculations reached to guess the host-guset interface among the hydrazone and numerous metal ions. The modeling structure of $\mathrm{H}_{2} \mathrm{~L}$ and these metal complexes appeared in Figure 3. In addition, the bond lengths and bond angles were calculated as showed in Figures 1S-13S.

\section{Molecular parameters}

The Quantum chemical parameters (the energies of the HOMO and LUMO) of calculated compounds achieved. Furthermore, (the total energy, electrostatic energy, exchange-correlation energy, binding energy, kinetic energy, sum of atomic energy, spin polarization energy, and dipole moment) intended. From the outcome data we can supposed that The isolated complexes were stable due to the difference energies between "LUMO and HOMO" are negative values (Figure 4). While, the minor values of "HOMO" energy designate to electron donating ability of molecule is weaker. On contrasting, the highest value of "HOMO" energy stated that the molecule is a decent electron donor. However, the complexes were more stable than free ligand due to the binding energy of complexes was higher than free ligand and difference between (HOMO and LUMO) in complexes was lower than difference between (HOMO and LUMO) in free ligand. Then, the free ligand is moderate values of dipole moment in than the isolated solid complexes that enhanced the powerful activities of free ligand and showed biological activity of ligand moderate between complexes.

\section{Global reactivity descriptors}

The LUMO ( $\pi$ acceptor) and HOMO ( $\pi$ donor) were essential parameters in quantum chemical measurements [25]. The values of HOMO was great surrounded on $\mathrm{O}_{13}>\mathrm{O}_{12}>\mathrm{O}_{11}>\mathrm{N}_{14}>\mathrm{C}_{16}$ atoms characteristic they capacity be the greatest well liked exposed with respect to nucleophilic attack. The value of $\mathrm{E}_{\text {номо }}, \mathrm{E}_{\mathrm{LUMO}}$ and their neighboring orbitals were a sign of the highest stability of complexes [26]. The definite overlap about "HOMO and LUMO" was typically a

\begin{tabular}{|c|c|c|c|c|c|c|}
\hline $\mathbf{U}_{\mathbf{2}} \mathbf{l} \mathbf{U}_{\mathbf{1}}$ & $\boldsymbol{\beta}$ & $\left.\mathbf{B} \mathbf{( c m}^{-1}\right)$ & $\left.\mathbf{D q} \mathbf{( c m}^{-1}\right)$ & Band position $\left.\mathbf{( c m}^{-1}\right)$ & $\boldsymbol{\mu e f f}(\mathbf{B M )}$ & Compound \\
\hline- & - & - & - & 16501,14925 & 2.1 & 2 \\
\hline 2.155 & 1.13 & 1101 & 935 & 23364,17857 & 5.1 & 4 \\
\hline 1.657 & .988 & 1029 & 977 & 28571,17094 & 3 & 5 \\
\hline
\end{tabular}

Table 3: Magnetic moments, electronic spectra, and ligand field parameters of metal complexes of $\mathrm{H}_{2} \mathrm{~L}$. 
major took into version many reactions. As outcome data, the ligand orbitals along with great molecular orbital coefficients value could be the best suitable web position correct complexation. Gap energy was main index for stability supported to report the kinetic stability and chemical reactivity of the compounds [27].

The DFT labeled the site selectivity of the molecular systems chemical reactivity and chemical reactivity. Global electrophilicity index $(\omega)$, Global hardness $(\eta)$ and global softness (S). Frontier energy of molecular orbitals $\left(\mathrm{E}_{\text {номо }}\right.$ and $\left.\mathrm{E}_{\text {LUмо }}\right)$, energy band gap $\left(\mathrm{E}_{\text {номо }}\right.$ -
$\left.\mathrm{E}_{\text {LUMO }}\right)$, chemical potential $(\mu)$, electronegativity $(\chi)[28,29]$, were listed

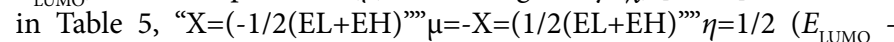
$\left.E_{\text {номо }}\right) "$ 'S $S=1 / 2 \eta " ' \omega=\mu^{2} / 2$ "

The converse importance of the global hardness as the softness 6 as follow:" $6=(1 / \eta)$ "Hardness linked to molecules stability according to Pauling the theory of electronegativity as the influence of "an atom in a molecule to attract electron to it-self". While, according to Parr et al. the electrophilicity index acted as energy value is low because of full electron transfer between donor and acceptor. The electrophilicity

\begin{tabular}{|c|c|c|c|c|c|c|c|c|c|c|}
\hline Comp. & $\begin{array}{c}\text { Total } \\
\text { Energy }(\mathrm{Ha})\end{array}$ & $\begin{array}{c}\text { Binding } \\
\text { Energy(Ha) }\end{array}$ & $\begin{array}{c}\text { Dipolemoment } \\
\text { (debye) }\end{array}$ & $\begin{array}{c}\text { HOMO } \\
\text { (ev) }\end{array}$ & $\begin{array}{l}\text { LUMO } \\
\text { (ev) }\end{array}$ & $\begin{array}{c}\text { Spin } \\
\text { polarization } \\
\text { energy }\end{array}$ & $\begin{array}{l}\text { Exchange- } \\
\text { correlation } \\
\text { Energy(Ha) }\end{array}$ & $\begin{array}{l}\text { Electrostatic } \\
\text { Energy }(\mathrm{Ha})\end{array}$ & $\begin{array}{c}\text { Kinetic } \\
\text { Energy }(\mathrm{Ha})\end{array}$ & $\begin{array}{l}\text { Sum of atomic } \\
\text { Energies }(\mathrm{Ha})\end{array}$ \\
\hline 1 & -1006 & -6.187 & 7.399 & -5.829 & -3.112 & 2.189 & 2.433 & 2.433 & -13.525 & -100 \\
\hline 2 & -2657 & -14.572 & 5.522 & -4.960 & -4.761 & 4.814 & 5.338 & -0.964 & -23.760 & -2463 \\
\hline 3 & -2665 & -13.871 & 11.349 & -4.482 & -4.357 & 4.133 & 5.345 & -0.850 & -22.499 & -2789 \\
\hline 4 & -2665 & -15.459 & 10.230 & -3.837 & -3.649 & 4.766 & 6.865 & -0.348 & -26.743 & -2650 \\
\hline 5 & -2664 & -8.685 & 7.3196 & -4.671 & -3.562 & 2.324 & 3.275 & -1.491 & -12.794 & -2256 \\
\hline 6 & -4465 & -15.459 & 6.750 & -3.631 & -2.583 & 1.958 & 3.202 & 2.891 & -14.970 & -2225 \\
\hline
\end{tabular}

Table 4: The molecular parameters of the ligand and its complexes.

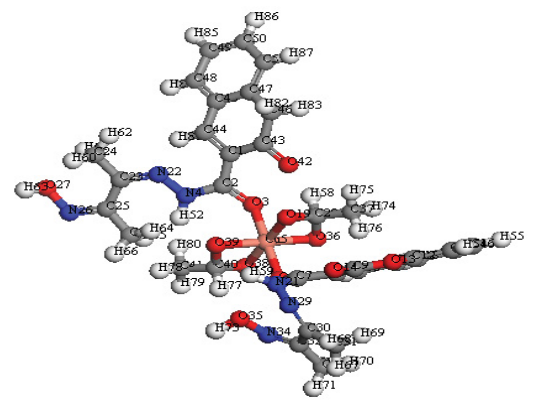

(A)

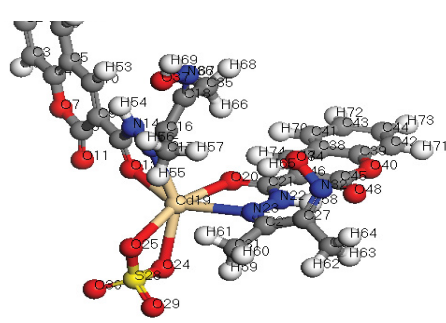

(C)

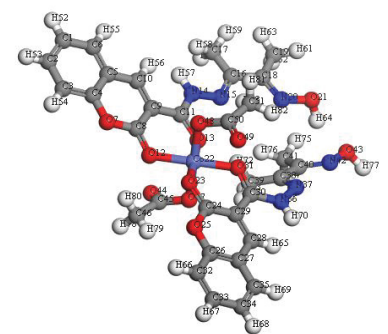

E)

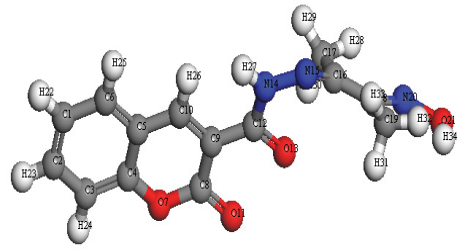

(B)

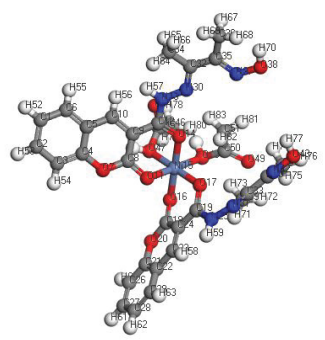

(D)

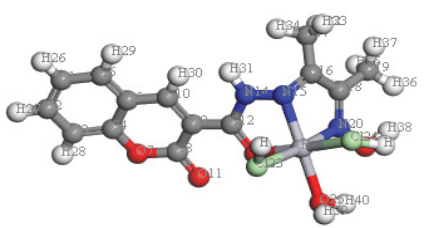

(F)

Figure 3: Molecular modeling of $(\mathrm{A}) \mathrm{H}_{2} \mathrm{~L}$, (B) $\left[\mathrm{Cu}\left(\mathrm{H}_{2} \mathrm{~L}\right)_{2}(\mathrm{OAc})_{2}\right],(\mathrm{C})\left[\mathrm{Cd}\left(\mathrm{H}_{2} \mathrm{~L}\right)_{2}\left(\mathrm{SO}_{4}\right)\right],(\mathrm{D})\left[\mathrm{Ni}_{2}\left(\mathrm{H}_{2} \mathrm{~L}\right)_{2}(\mathrm{OAc})_{2}\right],(\mathrm{E})\left[\mathrm{Co}\left(\mathrm{H}_{2} \mathrm{~L}\right)_{2}(\mathrm{OAc})_{2}\right],(\mathrm{F})\left[\mathrm{Hg}\left(\mathrm{H}_{2} \mathrm{~L}\right)\left(\mathrm{H}_{2} \mathrm{O}\right) \mathrm{Cl}_{2}\right]$ 


\section{HOMO}

(A)

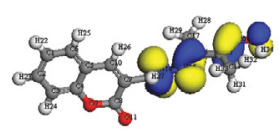

B)

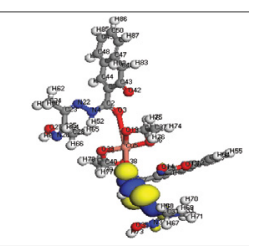

(C)

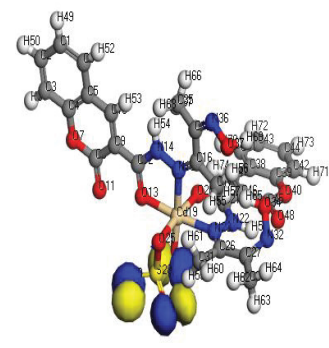

(D)

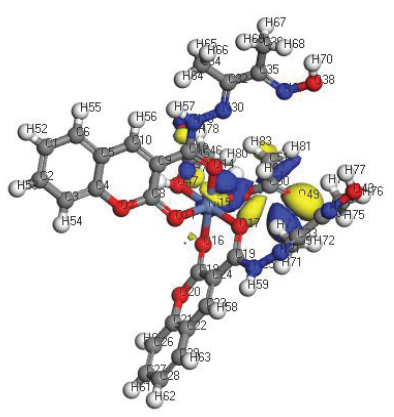

(E)

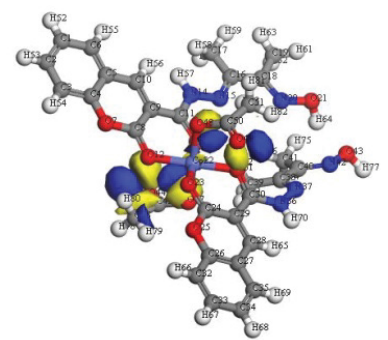

LUMO
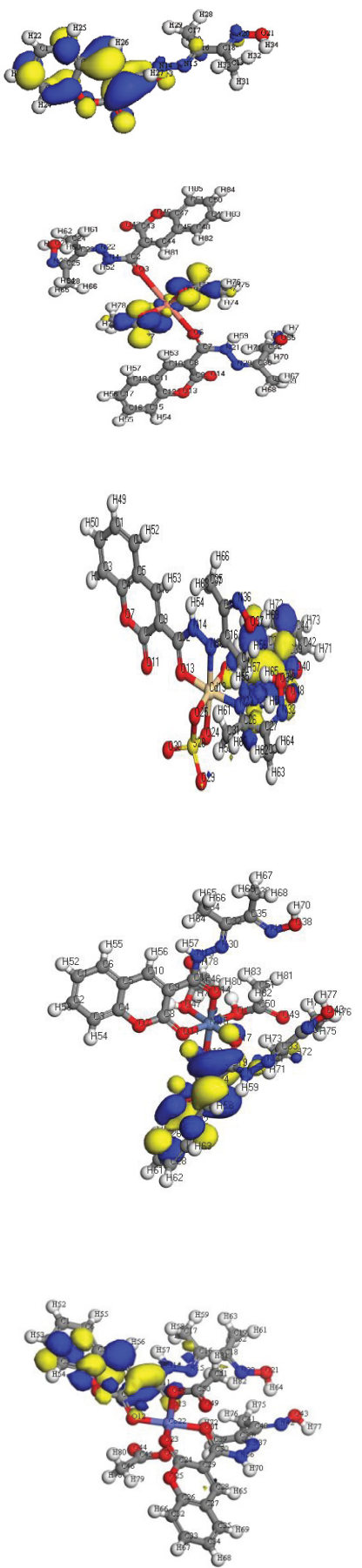

Figure 4: The HOMO and LUMO of $(A) \mathrm{H}_{2} \mathrm{~L}$, (B) $\left.\left[\mathrm{Cu}\left(\mathrm{H}_{2} \mathrm{~L}\right)_{2}(\mathrm{OAc})_{2}\right],(\mathrm{C})\left[\mathrm{Cd}\left(\mathrm{H}_{2} \mathrm{~L}\right)_{2}\left(\mathrm{SO}_{4}\right)\right],(\mathrm{D})\left[\mathrm{Ni}_{2} \mathrm{H}_{2} \mathrm{~L}\right)_{2}(\mathrm{OAc})_{2}\right],(\mathrm{E})\left[\mathrm{Co}\left(\mathrm{H}_{2} \mathrm{~L}\right)_{2}(\mathrm{OAc})_{2}\right],(\mathrm{F})\left[\mathrm{Hg}\left(\mathrm{H}_{2} \mathrm{~L}\right)(\mathrm{Cl})_{2}\left(\mathrm{H}_{2} \mathrm{O}\right)\right]$.

is used to descriptor of reactivity that agrees quantitative organization of the global electrophilic environment of a molecule within a relative scale. Besides, to recognize the toxicity of numerous pollutants in terms of reactivity and site selectivity.

\section{Molecular electrostatic potential (MEP) of $\mathrm{H}_{2} \mathrm{~L}$}

The "MEP" was measured a good descriptor for extensive position for (nucleophilic and electrophilic attack) [23]. In the current study, 3D designs of "MEP" were wan for the ligand and its metal complexes (Figure 5). Constructed on the "MEP", one can mostly order the electron-rich area with has red color of a map which prefer site for electrophilic attack. However, the electron-poor region has blue color favors site for nucleophilic attack [30]. Nevertheless, the green region point to neutral electrostatic potential region. 


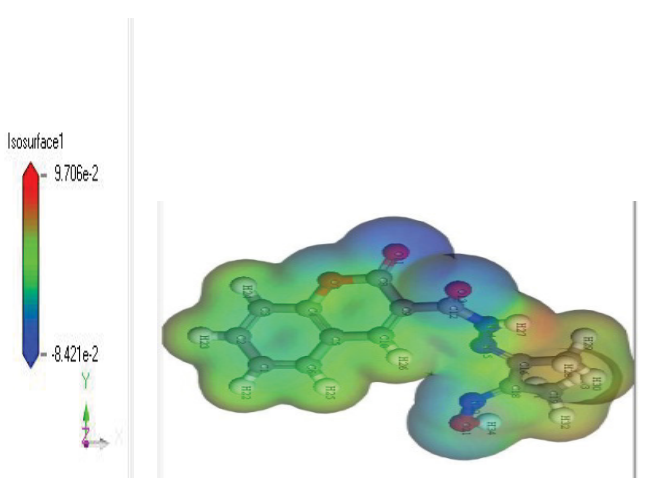

(A)

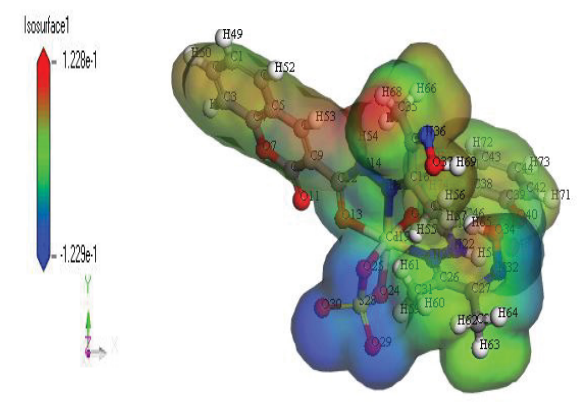

( C)

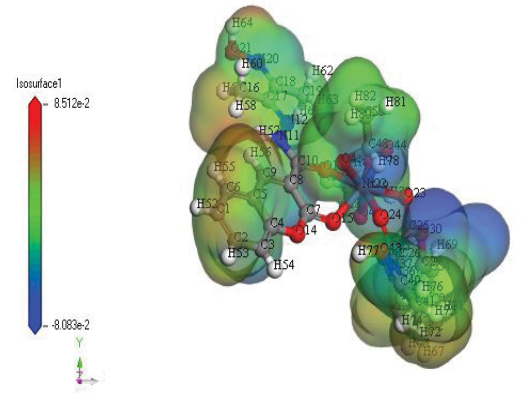

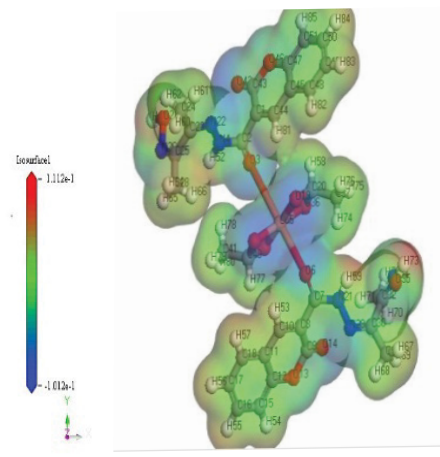

(B)

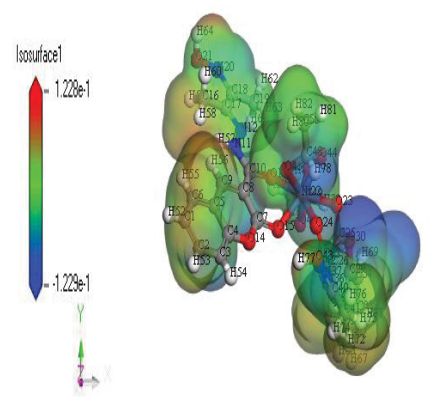

(D)

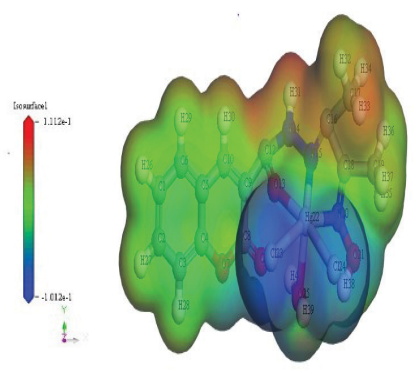

( F)

Figure 5: Molecular electrostatic potential map for $(\mathrm{A}) \mathrm{H}_{2} \mathrm{~L}$, (B) $\left[\mathrm{Cu}\left(\mathrm{H}_{2} \mathrm{~L}\right)_{2}(\mathrm{OAc})_{2}\right],(\mathrm{C})\left[\mathrm{Cd}\left(\mathrm{H}_{2} \mathrm{~L}\right)_{2}\left(\mathrm{SO}_{4}\right)\right],(\mathrm{D})\left[\mathrm{Ni}_{(}\left(\mathrm{H}_{2} \mathrm{~L}\right)_{2}(\mathrm{OAc})_{2}\right],(\mathrm{E})\left[\mathrm{Co}\left(\mathrm{H}_{2} \mathrm{~L}\right)_{2}(\mathrm{OAc})_{2}\right],(\mathrm{F})\left[\mathrm{Hg}\left(\mathrm{H}_{2} \mathrm{~L}\right)(\mathrm{Cl})_{2}\left(\mathrm{H}_{2} \mathrm{O}\right)\right]$.

\section{Local reactivity descriptors}

The fukui function is very vital then universal reactivity descriptors in DFT [31,32]. This function is derived from electron density, $(\rho(r))$, with impudence to $(\mathrm{N})$ is total number of electrons of the system, below $(v(r))$ is constant external potential,

$$
\rho(r)=\left(\frac{\partial \rho(r)}{\partial N}\right)_{v(r)}
$$

The Fukui function shows the tendency of the electronic density to collapse at assumed site upon accepting or donating electrons [33]. There are three kinds of Fukui function, which are specifically $f^{+}{ }_{\mathrm{k}}$ for nucleophilic attack, $f_{\mathrm{k}}^{-}$for electrophilic attack and $f^{0}{ }_{\mathrm{k}}$ for radical

$$
\text { “ } f^{+}{ }_{k}=q k(n+1)-q k(N) \text { ” For nucleophilic attack }
$$

$$
\begin{aligned}
& \text { “ } f^{-}{ }_{k}=q k(N)-q k(N-1) \text { " For electrophilic attack } \\
& \text { " } f^{0}{ }_{k}=1 / 2[q k(N+1)+q k(N-1)] \text { " For radical attack }
\end{aligned}
$$

And, local softness $\left(S^{+}{ }_{k}, S^{0}{ }_{k}, S^{0}{ }_{k}\right)$ and electrophilicity can be showed as the creation of the Fukui function by the following equations:

$$
\begin{aligned}
& \text { " }\left(S_{k}^{-}=S f^{-}{ }_{k}, S_{k}^{-}=S f^{-}{ }_{k}, S^{0}{ }_{k}=S f^{0}{ }_{k}\right) " \\
& \text { "( } \left.\omega_{k}^{-}=\omega f^{-}{ }_{k}, \omega_{k}^{-}=\omega f^{-}, \omega_{k}^{0}=\omega f^{0}{ }_{k}\right) "
\end{aligned}
$$

From the Fukui value of $\mathrm{H}_{2}$ Lwas described in Table 6 the reactivity order for the nucleophilic was predicted as $\mathrm{O}_{13}>\mathrm{O}_{12}>\mathrm{O}_{11}>\mathrm{N}_{14}>\mathrm{C}_{16}$. The calculated $f_{\mathrm{k}}^{-}$value predicted that the probable positions for electrophilic attack was $\mathrm{C}_{10}>\mathrm{O}_{11}>\mathrm{O}_{13}>\mathrm{C}_{9}>\mathrm{C}_{6}$ site and the radical attack was expected as $\mathrm{O}_{13}>\mathrm{O}_{11}>\mathrm{C}_{10}>\mathrm{O}_{11}>\mathrm{C}_{16}$ site. Whereas, the 
order for the nucleophilic in (Compound 2) $\mathrm{O}_{3}>\mathrm{C}_{23}>\mathrm{Cu}_{5}>\mathrm{O}_{6}>\mathrm{O}_{19}$ though calculated $f_{\mathrm{k}}$ value expected that the allowed sites for electrophilic attack was $\mathrm{O}_{19}>\mathrm{Cu}_{5}>\mathrm{O}_{6}>\mathrm{O}_{3}>\mathrm{C}_{20}$ site and radical attack was likely as $\mathrm{O}_{19}>\mathrm{Cu}_{5}>\mathrm{O}_{6}>\mathrm{C}_{23}>\mathrm{O}_{3}$ site. However, order for the nucleophilic in Compound $3 \mathrm{C}_{45}>\mathrm{N}_{23}>\mathrm{C}_{38}>\mathrm{O}_{34}>\mathrm{C}_{27}$ though calculated $f_{\mathrm{k}}^{-}$value predicted that the possible sites for electrophilic attack was $\mathrm{C}_{10}>\mathrm{O}_{11}>\mathrm{C}_{8}>\mathrm{O}_{13}$ site and the radical attack was predicted as $\mathrm{O}_{11}>\mathrm{N}_{36}>\mathrm{N}_{29}$ site. Yet order for the nucleophilic in Compound 4 $\mathrm{O}_{27}>\mathrm{C}_{35}>\mathrm{O}_{23}>\mathrm{Ni}_{22}>\mathrm{N}_{12}>\mathrm{O}_{21}$ though calculated $f_{\mathrm{k}}^{-}$value predicted that the promising sites for electrophilic attack was $\mathrm{Ni}_{22}>\mathrm{O}_{27}>\mathrm{O}_{39}>\mathrm{O}_{40}$ site and the radical attack was predicted as $\mathrm{O}_{27}>\mathrm{Ni}_{22}>\mathrm{O}_{39}>\mathrm{O}_{40}$ site. Yet, the order for the nucleophilic in Compound $5 \mathrm{O}_{40}>\mathrm{O}_{27}>\mathrm{O}_{6}>\mathrm{C}_{42}>\mathrm{C}_{44}$ though calculated $f_{\mathrm{k}}^{-}$value predicted that the possible sites for electrophilic attack was $\mathrm{O}_{27}>\mathrm{O}_{6}>\mathrm{Co}>\mathrm{C}_{44}$ site and the radical attack was predicted as $\mathrm{O}_{27}>\mathrm{Co}>\mathrm{C}_{44}=\mathrm{O}_{50}$ site. However, the order for the nucleophilic in Compound $6 \mathrm{O}_{21}>\mathrm{N}_{20}>\mathrm{N}_{14}>\mathrm{O}_{13}>\mathrm{N}_{1}$ though calculated $f_{\mathrm{k}}^{-}$value predicted that the possible sites for electrophilic attack was $\mathrm{C}_{10}>\mathrm{O}_{11}>\mathrm{C}_{9}>\mathrm{O}_{13}$ site and the radical attack was predicted as $\mathrm{C}_{10}>\mathrm{O}_{13}>\mathrm{C}_{16}>\mathrm{N}_{20}>\mathrm{C}_{9}$ site.

\section{Biological activity}

Antifungal activity: The results data showed that $\mathrm{H}_{2} \mathrm{~L}$ and their metal complexes have a significant activity against Candida albicans and Aspergillus flavus (Table 7). The (5) and (6) complexes were more effective against Aspergillus flavus than Candida albicans in association with the Colitrimazole as standard drug [34].

Antibacterial activity: The investigated compounds along with Ciprofloxacin (standard drug) and DMSO as (solvent control) carried separately for their antibacterial activity. The activity of the tested compounds was corresponding to the activity of Ciprofloxacin as a standard antibiotic. The MIC values showed that complexes (1 and 4) have the highest antibacterial activity (Table 7) [35].

Colorimetric assay for compounds that bind DNA: Methyl green reversibly binds to DNA, and the colored complex is stable at $(\mathrm{pH}=7)$, where methyl green only disappears at this $\mathrm{pH}$ value. Whereas, the DNA binding active compounds replace DNA from its methyl green complex. The displacement was measured by a spectrophotometric examine as a reduction in the absorbance at 630 $\mathrm{nm}$. The outcomes data shown that compounds (6 and $\mathbf{1})$ exhibited the maximum attraction to DNA, which established through retentive the complex at the source or by transferring for very small spaces, then by evaluating $\mathrm{IC}_{50}$ values. While, compounds $(\mathbf{3}, \mathbf{4}$ and 5) exhibited moderate activity (Table 8) [36].

Conductance measurement: The formation constants, association constants and Gibbs free energies of $\mathrm{H}_{2} \mathrm{~L}$ complexes were intended in (DMF-methanol) at room temperature (298.15K).

$$
\Lambda_{\mathrm{m}}=\left(\mathrm{K}_{\mathrm{s}}-\mathrm{K}_{\text {solv }}\right) \mathrm{K}_{\text {cell }} \times 1000 / \mathrm{C}
$$

$\left(\mathrm{K}_{\mathrm{s}}\right)$ is specific conductance value of the solution of $(\mathrm{Cu}(\Pi)$, $\mathrm{Ni}(\Pi)$ and $\mathrm{Co}(\Pi))$ in $5 \% \mathrm{DMF} / \mathrm{Methanol}$ at $(298.15 \mathrm{~K}) ;\left(\Lambda_{\mathrm{m}}\right)$ is molar conductance [37]; $\left(\mathrm{K}_{\text {solv }}\right)$ is the specific conductance of the solvent; (Kcell) is the cell constant (1); (C) is the molar concentration of the metal ion in solutions. The $(\Lambda \mathrm{o})$ is limiting molar conductance at infinite dilutions was valued for $(\mathrm{Cu}(\Pi), \mathrm{Co}(\Pi)$ and $\mathrm{Ni}(\Pi))$ ions in nonappearance of the ligand through extrapolating the relative between $((\Lambda \mathrm{m})$ and $(\mathrm{c}))$ to zero concentration for each line, $(\gamma \pm)$ is the activity co-efficient (Figure 6).

Likewise, the molar conductance $(\Lambda \mathrm{m})$ drawn against the molar ratio $[\mathrm{M} / \mathrm{L}]$ in the occurrence of ligand; where the metal concentration (M) and the ligand concentration (L). Dissimilar straight lines gained with sharp disruptions in existence of ligand express to molar ratios (Figure 7).

Association constants of the metal salt solutions: In absence of ligand, series of conduct metric series measurement carried out in $5 \% \mathrm{DMF} / \mathrm{Methanol}$. The Gibbs of free energy change of association $\left(\Delta \mathrm{G}_{\mathrm{A}}\right)$ of $\mathrm{Cu}(\Pi), \mathrm{Ni}(\Pi)$ and $\mathrm{Co}(\Pi)$ metal salt solutions were estimated from the association constant $\left(\mathrm{K}_{\mathrm{A}}\right)$ in using equation (2) $[38,39] \Delta \mathrm{G}_{\mathrm{A}}=-$ 2.303RT $\log \mathrm{K}_{\mathrm{A}}$ Where (R) is gas constant; in addition, (T) is absolute

\begin{tabular}{|c|c|c|c|c|c|c|c|c|c|c|}
\hline Compound & $E_{H(e v)}$ & $E_{L(e v)}$ & $E_{H}-E_{L}$ & $E_{L}-E_{H}$ & $\mathbf{x}_{(\mathrm{eV})}$ & $\mu_{(\mathrm{eV})}$ & $\eta_{(e V)}$ & $S_{(e V-1)}$ & $\omega_{(\mathrm{eV})}$ & $\sigma_{(\mathrm{eV})}$ \\
\hline 1 & 5.829 & 3.112 & 2.717 & 2.717 & 4.4705 & 4.4705 & 1.3585 & 0.67925 & 7.355675 & 0.736106 \\
\hline 2 & 5.153 & 5.075 & 0.078 & 0.078 & 5.114 & 5.114 & 0.039 & 0.0195 & 335.2498 & 25.64103 \\
\hline 3 & 4.482 & 4.357 & 0.125 & 0.125 & 4.4195 & 4.4195 & 0.0625 & 0.03125 & 156.2558 & 16 \\
\hline 4 & 3.837 & 3.649 & 0.188 & 0.188 & -3.743 & 3.743 & 0.094 & $0 . .047$ & 74.52154 & 10.6383 \\
\hline 5 & 3.859 & 3.696 & 0.163 & 0.163 & -3.7775 & 3.7775 & 0.0815 & 0.04075 & 87.54298 & 12.26994 \\
\hline 6 & 3.631 & 2.583 & 1.048 & 1.048 & -3.107 & 3.107 & 0.524 & 0.262 & 9.211306 & 1.908397 \\
\hline
\end{tabular}

Table 5: Calculated EHOMO, ELUMO, energy band gap (EH - EL), chemical potential $(\mu)$, electronegativity $(\mathrm{X})$, global hardness ( $\eta)$, softness $(\mathrm{S})$, global electrophilicity index $(\omega)$ and softness (6) for $\mathrm{H}_{2} \mathrm{~L}$ and its metal complexes.

\begin{tabular}{|c|c|c|c|}
\hline Radical attack & $\begin{array}{c}\text { Electrophilic } \\
\text { attack }\end{array}$ & Nucleophilic attack & Compound \\
\hline $\mathrm{O}_{13}>\mathrm{O}_{11}>\mathrm{C}_{10}>\mathrm{O}_{11}>\mathrm{C}_{16}$ & $\mathrm{C}_{10}>\mathrm{O}_{11}>\mathrm{O}_{13}>\mathrm{C}_{9}>\mathrm{C}_{6}$ & $\mathrm{O}_{13}>\mathrm{O}_{12}>\mathrm{O}_{11}>\mathrm{N}_{14}>\mathrm{C}_{16}$ & 1 \\
\hline $\mathrm{O}_{19}>\mathrm{Cu}_{5}>\mathrm{O}_{6}>\mathrm{C}_{23}>\mathrm{O}_{3}$ & $\mathrm{O}_{19}>\mathrm{Cu}_{5}>\mathrm{O}_{6}>\mathrm{O}_{3}>\mathrm{C}_{20}$ & $\mathrm{O}_{3}>\mathrm{C}_{23}>\mathrm{Cu}_{5}>\mathrm{O}_{6}>\mathrm{O}_{19}$ & 2 \\
\hline $\mathrm{O}_{11}>\mathrm{N}_{36}>\mathrm{N}_{29}$ & $\mathrm{C}_{10}>\mathrm{O}_{11}>\mathrm{C}_{8}>\mathrm{O}_{13}$ & $\mathrm{C}_{45}>\mathrm{N}_{23}>\mathrm{C}_{38}>\mathrm{O}_{34}>\mathrm{C}_{27}$ & 3 \\
\hline $\mathrm{O}_{27}>\mathrm{Ni}_{22}>\mathrm{O}_{39}>\mathrm{O}_{40}$ & $\mathrm{Ni}_{22}>\mathrm{O}_{27}>\mathrm{O}_{39}>\mathrm{O}_{40}$ & $\mathrm{O}_{27}>\mathrm{C}_{35}>\mathrm{O}_{23}>\mathrm{Ni}_{22}>\mathrm{N}_{12}>\mathrm{O}_{21}$ & 4 \\
\hline $\mathrm{O}_{27}>\mathrm{C}_{0}>\mathrm{C}_{44}=\mathrm{O}_{50}$ & $\mathrm{O}_{27}>\mathrm{O}_{6}>\mathrm{C}_{0}>\mathrm{C}_{44}$ & $\mathrm{O}_{40}>\mathrm{O}_{27}>\mathrm{O}_{6}>\mathrm{C}_{42}>\mathrm{C}_{44}$ & 5 \\
\hline $\mathrm{C}_{10}>\mathrm{O}_{13}>\mathrm{C}_{16}>\mathrm{N}_{20}>\mathrm{C}_{9}$ & $\mathrm{C}_{10}>\mathrm{O}_{11}>\mathrm{C}_{9}>\mathrm{O}_{13}$ & $\mathrm{O}_{21}>\mathrm{N}_{20}>\mathrm{N}_{14}>\mathrm{O}_{13}>\mathrm{N}_{15}$ & 6 \\
\hline
\end{tabular}

Table 6: Ordering the nucleophilic, electrophilic, and radical attack sites for $\mathrm{H}_{2} \mathrm{~L}$ and its metal complexes.

\begin{tabular}{|c|c|c|c|c|c|c|}
\hline Compound & E. coli & $\begin{array}{c}\boldsymbol{P} . \\
\text { aeuroginosa }\end{array}$ & S. aureus & $\begin{array}{c}\boldsymbol{B} . \\
\text { subtilis }\end{array}$ & $\begin{array}{c}\boldsymbol{C} . \\
\text { albicans }\end{array}$ & $\begin{array}{c}\boldsymbol{A} . \\
\text { flavus }\end{array}$ \\
\hline Ampicillin & 125 & 187.5 & 187.5 & 93.7 & - & - \\
\hline Colitrimazole & - & - & - & & 5.8 & 3.9 \\
\hline 1 & 500 & 250 & 250 & 187.5 & 23.4 & 15.6 \\
\hline 2 & NA & 500 & 250 & 187.5 & 31.2 & 23.4 \\
\hline 3 & 250 & 187.5 & 375 & 250 & 46.9 & 62.5 \\
\hline 4 & 187.5 & 125 & 187.5 & 93.7 & 15.6 & 7.8 \\
\hline 5 & NA & 750 & 500 & 375 & 93.7 & 93.7 \\
\hline 6 & NA & NA & NA & NA & 375 & 500 \\
\hline
\end{tabular}

Table 7: Antibacterial and antifungal activities in terms of MIC $(\mu \mathrm{g} / \mathrm{mL})$. 


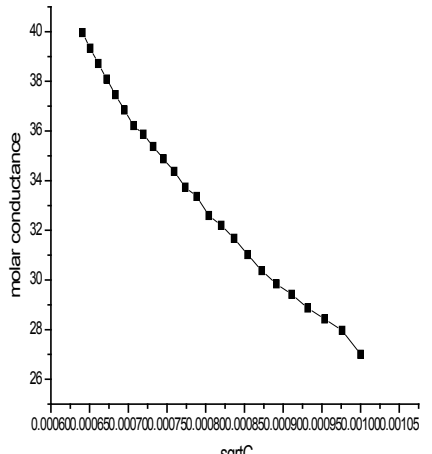

(A)

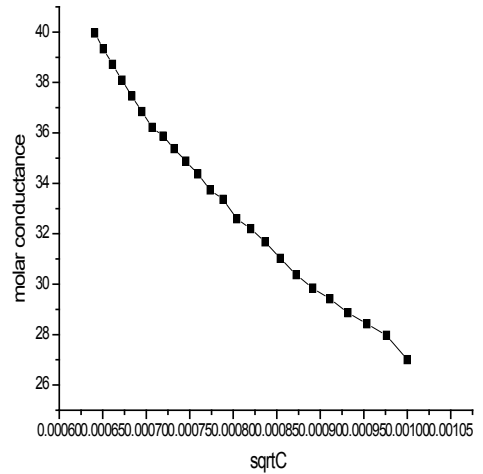

(B)

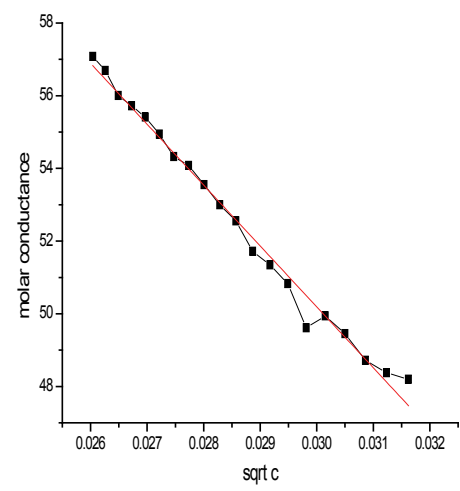

(C)

Figure 6: The relation between molar conductance $(\wedge \mathrm{m})$ and $\mathrm{C}$ of $\mathrm{Cu}(\Pi) \mathrm{Ni}(\Pi)$ and $\mathrm{Co}(\Pi)$ metal ions in $\mathrm{DMF}-\mathrm{methanol}$ at $298.15 \mathrm{~K}$

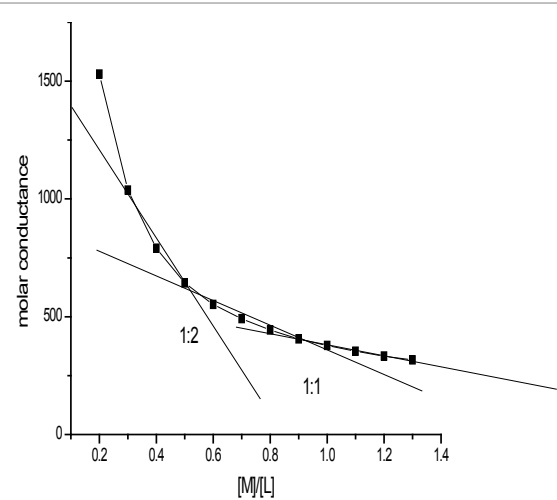

(A)

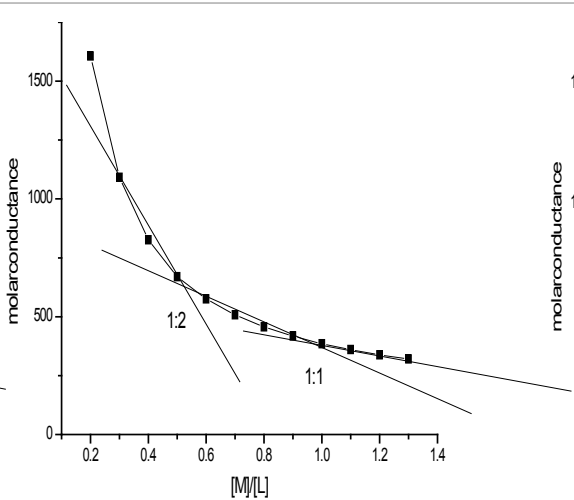

(B)

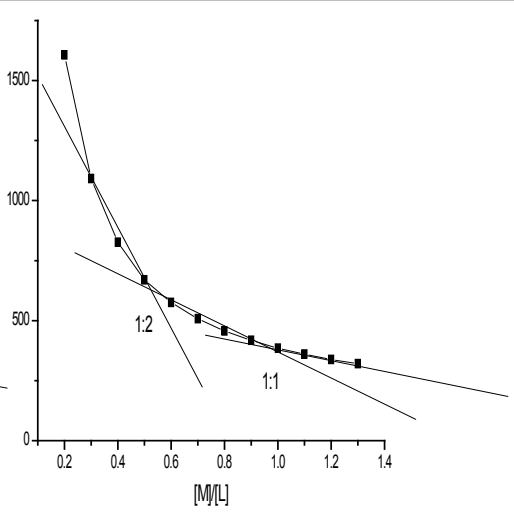

(C)

Figure 7: The relation between molar conductance $\left(\wedge_{\mathrm{m}}\right)$ and $[\mathrm{M}] /[\mathrm{L}]$ in DMF-methanol at $298.15 \mathrm{~K}$.

\begin{tabular}{|c|c|}
\hline Compound & DNA/methyl green $\left(\mathbf{I C}_{\mathbf{5 0}}, \boldsymbol{\mu g} / \mathbf{m l}\right)$ \\
\hline 1 & $42.8 \pm 2.2$ \\
\hline 2 & $46.7 \pm 2.6$ \\
\hline 3 & $49.6 \pm 2.5$ \\
\hline 4 & $39.3 \pm 2.0$ \\
\hline 5 & $58.4 \pm 2.9$ \\
\hline 6 & $82.5 \pm 4.1$ \\
\hline
\end{tabular}

Table 8: DNA/methyl green colorimetric assay of the DNA-binding compounds.

\begin{tabular}{|c|c|c|c|c|c|}
\hline$\Delta \mathbf{G A}$ & $\mathbf{K}_{\mathbf{d}}$ & $\mathbf{K}_{\mathbf{a}}$ & $\mathbf{Y} \mathbf{\pm}$ & $\mathbf{m}^{\wedge}$ & $\mathbf{C}$ \\
\hline-22.5381 & 0.000113 & 8871.745 & 0.771178 & 32.4625 & $8.2 \mathrm{E}-04$ \\
\hline-22.399 & 0.000119 & 8387.894 & 0.771563 & 33.66 & 0.000784 \\
\hline-22.2631 & 0.000126 & 7940.367 & 0.77195 & 34.8475 & 0.000755 \\
\hline-22.1536 & 0.000132 & 7597.43 & 0.772721 & 35.8875 & 0.000727 \\
\hline-22.0234 & 0.000139 & 7208.527 & 0.773108 & 37.05 & 0.000702 \\
\hline
\end{tabular}

Table 9: Association constants and Gibbs free energies of association for $\mathrm{Cu}(\mathrm{II})$ in DMF-methanol at $298.15 \mathrm{~K}$.

temperature. The intended Gibbs free energies appeared on Tables 9-11. Formation constant for the complexation of the metal salt with ligand. The formation constant (Kf) of $\mathrm{Cu}(\Pi), \mathrm{Co}(\Pi)$ and $\mathrm{Ni}(\Pi)$ complexes were estimated from the direct relation of $[\mathrm{M} / \mathrm{L}]$ against $(\Lambda \mathrm{m})$, by using equation(3) $[40,41]$

$\mathrm{Kf}=\Lambda_{\mathrm{m}}-\Lambda_{\mathrm{obs}} /\left(\Lambda_{\mathrm{obs}}-\Lambda_{\mathrm{ML}}\right)[\mathrm{L}]$ " Anywhere, $\left(\Lambda_{\mathrm{m}}\right)$ is the molar conductance of the $\mathrm{Cu}(\Pi), \mathrm{Co}(\Pi)$ and $\mathrm{Ni}(\Pi)$ ions previously adding of the ligand,

\begin{tabular}{|c|c|c|c|c|c|}
\hline $\mathbf{\Delta G A}$ & $\mathbf{K}_{\mathrm{d}}$ & $\mathbf{K}_{\mathrm{a}}$ & $\mathbf{Y} \mathbf{\pm}$ & $\wedge$ & $\mathbf{C}$ \\
\hline-20.2006 & 0.000289 & 3455.886 & 0.731973 & 52.5525 & $8.2 \mathrm{E}-04$ \\
\hline-20.1361 & 0.000297 & 3367.069 & 0.734436 & 53.55 & 0.000784 \\
\hline-20.1002 & 0.000301 & 3318.619 & 0.737215 & 54.325 & 0.000755 \\
\hline-20.0834 & 0.000303 & 3296.246 & 0.740144 & 54.945 & 0.000727 \\
\hline
\end{tabular}

Table 10: Association constants and Gibbs free energies of association for $\mathrm{Ni}(\mathrm{II})$ in DMF-methanol at $298.15 \mathrm{~K}$.

\begin{tabular}{|c|c|c|c|c|c|}
\hline $\boldsymbol{\Delta G A}$ & $\mathbf{K}_{\mathrm{d}}$ & $\mathbf{K}_{\mathrm{a}}$ & $\mathbf{V \pm}$ & $\mathbf{m}^{\wedge}$ & $\mathbf{C}$ \\
\hline-22.5815 & 0.000111 & 9028.376 & 0.771924 & 30.9925 & $8.2 \mathrm{E}-04$ \\
\hline-22.4203 & 0.000118 & 8460.215 & 0.771922 & 32.2575 & 0.000784 \\
\hline-22.2858 & 0.000125 & 8013.261 & 0.772326 & 33.39 & 0.000755 \\
\hline-22.1787 & 0.00013 & 7674.725 & 0.77313 & 34.375 & 0.000727 \\
\hline-22.05 & 0.000137 & 7286.287 & 0.773534 & 35.4825 & 0.000702 \\
\hline
\end{tabular}

Table 11: Association constants and Gibbs free energies of association for $\mathrm{Co}(\mathrm{II})$ in DMF-methanol at $298.15 \mathrm{~K}$.

$\left(\Lambda_{\mathrm{obs}}\right)$ is the molar conductance of solution in titration and $\left(\Lambda_{\mathrm{ML}}\right)$ is the molar conductance of the complex. Similarly, the Gibbs free energy of the formation for each $\mathrm{Cu}(\Pi)$, $\mathrm{Co}(\Pi)$ and $\mathrm{Ni}(\Pi)$ complex was calculated from the formation constants by equation (4) (Tables 12-14) [42].

\section{$\Delta \mathrm{Gf}=-\mathrm{RT} \ln K \mathrm{f}$}

Association and formation constants for metal complexes with $\left(\mathrm{H}_{2} \mathrm{~L}\right)$ in 5\% (DMF-methanol) solutions at 298.15K: The Gibbs free energies of association and association constants for $(\mathrm{Cu}(\Pi), \mathrm{Ni}(\Pi)$ 
and Co $(\Pi)$ ) ions complexes in 5\% (DMF-methanol) solutions at (298.15 K) were calculated by applying relations (3), (4). The results were presented and collected on Tables 15-17 that, there two straight lines with one breakdown characteristic the foundation of (1:1) and $(1: 2)(\mathrm{M} / \mathrm{L})$ stoichiometric complexes for $(\mathrm{Cu}(\Pi), \mathrm{Ni}(\Pi)$ and $\mathrm{Co}(\Pi))$, respectively in mixed solvent at $(298.15 \mathrm{~K})$.

\section{Conclusions}

In this paper, $\mathrm{Cu}(\mathrm{II}), \mathrm{Ni}(\mathrm{II}), \mathrm{Hg}$ (II) $\mathrm{Co}(\mathrm{II})$ and $\mathrm{Cd}(\mathrm{II})$ with $\mathrm{N}^{\prime}$-(3 (hydroxyimino)butan-2-ylidene)-2-oxo-2H-chromene-3carbohydrazide $\left(\mathrm{H}_{2} \mathrm{~L}\right)$ were synthesised and characterized by various methods). The consequences showed that the $\mathrm{H}_{2} \mathrm{~L}$ the IR spectra shown that ligand behavior as monodentate, bidentate and/or tridentate ligand. The electronic spectrum as well as magnetic moments proposing geometry of complexes is octahedral structure. DFT calculations done to calculate the host-gust interaction between the hydrazone and several metal ions. Moreover, the ligand and its complexes carried for biological activity. The result data shown that the $\mathrm{H}_{2} \mathrm{~L}, \mathrm{Cd}(\Pi)$ and $\mathrm{Ni}(\Pi)$ complex have highest biological activity.

\begin{tabular}{|c|c|c|c|c|c|}
\hline $\mathbf{A G A}$ & $\mathbf{K}_{\mathrm{d}}$ & $\mathbf{K}_{\mathbf{a}}$ & $\mathbf{Y} \mathbf{\pm}$ & $\mathbf{m}^{\wedge}$ & $\mathbf{C}$ \\
\hline-27.3409 & $1.62 \mathrm{E}-05$ & 61562.72 & 0.929782 & 551.8333 & $5.6 \mathrm{E}-05$ \\
\hline-27.9395 & $1.28 \mathrm{E}-05$ & 78374.19 & 0.927636 & 461.0038 & 0.000071111 \\
\hline-28.6279 & $9.67 \mathrm{E}-06$ & 103459.4 & 0.927754 & 383.8894 & 0.000085106 \\
\hline-29.3116 & $7.34 \mathrm{E}-06$ & 136309.4 & 0.929037 & 322.5783 & 0.00009759 \\
\hline-29.2742 & $7.45 \mathrm{E}-06$ & 134270.6 & 0.927509 & 316.3642 & 0.000104 \\
\hline
\end{tabular}

Table 12: Association constants and Gibbs free energies of association for $\mathrm{Cu}(\mathrm{II})$ with (H2L) in DMF-methanol at $298.15 \mathrm{~K}$.

\begin{tabular}{c|c|c|c|c|}
\hline $\mathbf{G A}$ & $\mathbf{K}_{\mathbf{d}}$ & $\mathbf{K}_{\mathrm{a}}$ & $\mathbf{m}^{\wedge}$ & $\mathbf{C}$ \\
\hline-27.4512 & $1.55 \mathrm{E}-05$ & 64363.34 & 575.125 & $8.2 \mathrm{E}-04$ \\
\hline-28.1171 & $1.19 \mathrm{E}-05$ & 84194.44 & 474.61223 & 0.000784 \\
\hline-28.7969 & $9.03 \mathrm{E}-06$ & 110758.4 & 395.15657 & 0.000755 \\
\hline-29.4583 & $6.91 \mathrm{E}-06$ & 144618.3 & 333.84548 & 0.000727 \\
\hline-29.5312 & $6.71 \mathrm{E}-06$ & 148933.5 & 320.139 & 0.000702 \\
\hline
\end{tabular}

Table 13: Association constants and Gibbs free energies of association for $\mathrm{Ni}(\mathrm{II})$ with $\left(\mathrm{H}_{2} \mathrm{~L}\right)$ in DMF-methanol at $298.15 \mathrm{~K}$.

\begin{tabular}{|c|c|c|c|c|c|}
\hline $\mathbf{\Delta G A}$ & $\mathbf{K}_{\mathbf{d}}$ & $\mathbf{K}_{\mathbf{a}}$ & $\mathbf{Y \pm}$ & ${ }_{\mathbf{m}}^{\mathbf{\wedge}}$ & $\mathbf{C}$ \\
\hline-26.9375 & $1.91 \mathrm{E}-05$ & 52318.89 & 0.927746 & 609.1667 & $5.6 \mathrm{E}-05$ \\
\hline-27.4995 & $1.52 \mathrm{E}-05$ & 65631.19 & 0.925152 & 514.41323 & $7.111 \mathrm{E}-05$ \\
\hline-28 & $1.25 \mathrm{E}-05$ & 80310.86 & 0.923982 & 443.88352 & $8.511 \mathrm{E}-05$ \\
\hline-28.5329 & $1 \mathrm{E}-05$ & 99567.54 & 0.924217 & 384.62101 & $9.759 \mathrm{E}-05$ \\
\hline-26.1951 & $9.8 \mathrm{E}-06$ & 101997.2 & 0.923189 & 371.15 & 0.000104 \\
\hline
\end{tabular}

Table 14: Association constants and Gibbs free energies of association for Co(II) with $\left(\mathrm{H}_{2} \mathrm{~L}\right)$ in DMF-methanol at $298.15 \mathrm{~K}$.

\section{References}

1. Al-Bayati RI, Al-Amiery AAH, Al-Majedy YK (2010) Design, synthesis and bioassay of novel coumarins. Afr J Pure Appl Chem 4: 74-86.

2. Jain PK, Joshi H (2012) Coumarin: Chemical and pharmacological profile. J App Pharm Sci 6: 236

3. Venugopala KN, Rashmi V, Odhav B (2013) Review on natural coumarin lead compounds for their pharmacological activity. BioMed Res Int 2013: 963248.

4. Fuller RW, Bokesch HR, Gustafson KR, McKee TC, Cardellina JH, et al. (1994) HIV-inhibitory coumarins from latex of the tropical rainforest tree Calophyllum teysmannii var. inophylloide. Bioorg Med Chem Lett 4: 1961-1964.

5. AL-haj hussien F, Merza J, Karam A (2016) Eco-friendly Synthesis of Coumarin Derivatives via Pechmann Condensation Using Heterogeneous Catalysis. Chem Mater Res 8: 16-20.

6. Patel KA, Patel CJ, Dholariya RH, Patel SK, Patel KV, et al. (2013) Synthesis Characterization and Biological Evaluation: Copper(II) Complexes of Hydroxy coumarins with Ciprofloxacin. Res J Pharm Biol Chem Sci 4: 564.

7. Jani GR, Vyas KB, Franco Z (2009) Preparation and antimicrobial activity of s-triazine hydrazones of 7-hydroxy coumarin and their metal complexes. $J$ Chem 6: 1228-1232.

8. Rohini K, Srikumar PS (2014) Therapeutic Role of Coumarins and CoumarinRelated Compounds. J Thermodyn Catal 5: 130

9. Shahare SP, Ingle VN, Paliwal LJ (2012) Synthesis of 4-(2'-Alkyl/Ary Benzimidazolo N-1-Yl-Methyl-) 5, 7 Dihydroxy Coumarins. Int J Chem Anal Sci 3: 1583-1584.

10. Vianna DR, Hamerski L, Figueiró F, Bernardi A, Visentin LC, et al. (2012) Selective cytotoxicity and apoptosis induction in glioma cell lines by 5-oxygenated-6, 7-methylenedioxycoumarins from Pterocaulon species. Eur J Med Chem 57: 268-274.

11. Delley B (2002) Hardness conserving semilocal pseudopotentials. Phys Rev B 66: 155125

12. Modeling and Simulation Solutions for Chemicals and Materials Research. Materials Studio (Version 5.0), Accelrys software Inc., San Diego, USA.

13. Hehre WJ (1986) Ab initio molecular orbital theory. Wiley-Interscience.

14. Kessi A, Delley B (1998) Density functional crystal vs. cluster models as applied to zeolites. Int J Quantum Chem 68: 135-144.

15. Hammer B, Hansen LB, Nørskov JK (1999) Improved adsorption energetics within density-functional theory using revised Perdew-Burke-Ernzerhof functionals. Phys Rev B 59: 7413.

16. Refat HM, Fadda AA (2013) Synthesis and antimicrobial activity of some nove hydrazide, benzochromenone, dihydropyridine, pyrrole, thiazole and thiophene derivatives. Eur J Med Chem 70: 419-426.

17. Ghaly MA, El-Bendary ER, Shehata IA, Bayomi SM, Habib SE (2012) Synthesis, antimicrobial activity, DNA-Binding affinity and molecular docking of certain 1 , 2, 4-triazolo [1, 5-a] pyrimidines as nalidixic acid isosteres. J Am Sci 8: 617-628.

18. Anitha C, Sumathi S, Tharmaraj P, Sheela CD (2012) Synthesis, characterization, and biological activity of some transition metal complexes derived from novel

\begin{tabular}{|c|c|c|c|c|c|c|c|c|c|}
\hline$\Delta G_{f}$ & $\log _{k f}$ & K & [L] & $\Lambda_{\mathrm{obs}}$ & $\Lambda_{\mathrm{mL}}$ & $\Lambda_{m}$ & [M] & [L] & {$[M] /[L]$} \\
\hline-20.604 & 3.549689 & 3545.594 & $8.42 E-5$ & 642.6 & 147.8 & 790.4 & 0.00004762 & 0.0000952 & $1: 2$ \\
\hline-28.7639 & 4.955479 & 90256.57 & $2.57 \mathrm{E}-5$ & 378.4 & 264.25 & 642.6 & 8.5106E-05 & 0.0000851 & $1: 1$ \\
\hline
\end{tabular}

Table 15: Formation constant and Gibbs free energies for $\mathrm{Cu}(\mathrm{II})$ in DMF-methanol at $298.15 \mathrm{~K}$.

\begin{tabular}{|c|c|c|c|c|c|c|c|c|c|}
\hline$\Delta \mathbf{G}_{\mathrm{f}}$ & $\log _{k f}$ & K & [L] & $\Lambda_{\text {obs }}$ & $\Lambda_{\mathrm{mL}}$ & $\Lambda_{\mathrm{m}}$ & [M] & [L] & {$[M] /[L]$} \\
\hline-20.6696 & 3.560985 & 3639.023 & $8.4 \mathrm{E}-5$ & 669.9 & 156.9 & 826.8 & 0.00004762 & 0.0000952 & $1: 2$ \\
\hline-29.6165 & 5.102368 & 126581 & $2.23 E-5$ & 385.4 & 284.5 & 669.9 & 8.5106E-05 & 0.0000851 & $1: 1$ \\
\hline
\end{tabular}

Table 16: Formation constant and Gibbs free energies for Ni(II) in DMF-methanol at $298.15 \mathrm{~K}$.

\begin{tabular}{|c|c|c|c|c|c|c|c|c|c|}
\hline$\Delta \mathbf{G f}$ & $\log \mathbf{k f}$ & $\mathbf{K}$ & [L] & $\Lambda_{\text {obs }}$ & $\Lambda_{\mathrm{MI}}$ & $\Lambda_{\mathrm{m}}$ & [M] & [L] & {$[\mathrm{M}] /[\mathrm{L}]$} \\
\hline 20.2644 & 3.54972 & 3545.843 & 8.42E05 & 693 & 159.4 & 852.4 & 0.00004762 & 0.0000952 & $1: 2$ \\
\hline 26.3435 & 4.614608 & 41172.59 & 3.49E05 & 435.9 & 257.075 & 693 & 8.5106E-05 & 0.0000851 & $1: 1$ \\
\hline
\end{tabular}

Table 17: Formation constant and Gibbs free energies for Co(II) in DMF-methanol at $298.15 \mathrm{~K}$. 
Citation: Zaky RR, Ibrahim KM, Abouelala EE (2016) Synthesis, Characterization and Biological Approach of N'-(3-(Hydroxy Imino) Butan-2-ylidene)-2-Oxo2H-Chromene-3-Carbohydrazide Complexes. Mod Chem appl 5: 198. doi: 10.4172/2329-6798.1000198

Page 10 of 10

hydrazone azo schiff base ligand. Int J Inorg Chem 2011: 493942.

19. Zaky RR, Yousef TA, Ibrahim KM (2012) Co (II), Cd (II), Hg (II) and U (VI) $\mathrm{O}_{2}$ complexes of o-hydroxyacetophenone [N-(3-hydroxy-2-naphthoyl)] hydrazone: physicochemical study, thermal studies and antimicrobial activity. Spectrochim Acta A Mol Biomol Spectrosc 97: 683-694.

20. Mohareb RM, Fleita DH, Sakka OK (2010) Novel synthesis of hydrazidehydrazone derivatives and their utilization in the synthesis of coumarin, pyridine, thiazole and thiophene derivatives with antitumor activity. Molecules 16: 16-27.

21. Zaky RR, Ibrahim KM, Gabr IM (2011) Bivalent transition metal complexes of o-hydroxyacetophenone [N-(3-hydroxy-2-naphthoyl)] hydrazone: Spectroscopic, antibacterial, antifungal activity and thermogravimetric studies. Spectrochim Acta A Mol Biomol Spectrosc 81: 28-34.

22. Patil SA, Unki SN, Kulkarni AD, Naik VH, Badami PS (2011) Co (II), Ni (II) and $\mathrm{Cu}$ (II) complexes with coumarin-8-yl Schiff-bases: spectroscopic, in vitro antimicrobial, DNA cleavage and fluorescence studies. Spectrochim Acta A Mol Biomol Spectrosc 79: 1128-1136.

23. Sangeetha CC, Madivanane R, Pouchaname V (2013) The Vibrational Spectroscopic (FT-IR \& FTR) study and HOMO \& LUMO analysis of 6-Methyl Quinoline using DFT Studies. Arch Phys Res 4: 67-77.

24. Cotton FA, Wilkinson G, Murillo AC, Bochmann M (2003) Advanced Inorganic Chemistry. (6 $6^{\text {th }}$ Edn.), John Wiley \& Sons Inc., USA.

25. Yousef TA, El-Reash GA, El Morshedy RM (2012) Quantum chemical calculations, experimental investigations and DNA studies on (E)-2-((3hydroxynaphthalen-2-yl) methylene)- $\mathrm{N}$-(pyridin-2-yl) hydrazinecarbothioamide and its $\mathrm{Mn}$ (II), Ni (II), Cu (II), Zn (II) and Cd (II) complexes. Polyhedron 45: 71-85

26. Pearson RG (1989) Absolute electronegativity and hardness: applications to organic chemistry. J Org Chem 54:1423-1430.

27. Padmanabhan J, Parthasarathi R, Subramanian V, Chattaraj PK (2007) Electrophilicity-based charge transfer descriptor. J Phys Chem A 111: 13581361.

28. Parr RG, Chattaraj PK (1991) Principle of maximum hardness. J Am Chem Soc 113: $1854-1855$.

29. Pauling $L$ (1960) The Nature of the Chemical Bond. ( $3^{\text {rd }}$ Edn.). Cornell University Press, Ithaca, New York, USA.
30. Siddappa K, Mayana NS (2014) Synthesis, Spectroscopic Characterization and Biological Evaluation Studies of 5-Bromo-3-(((hydroxy-2-methylquinolin-7yl) methylene) hydrazono) indolin-2-one and Its Metal (II) Complexes. Bioinorg Chem Appl 2014: 483282.

31. Tanak H, Koysal $Y$, Isik $S$, Yaman $H$, Ahsen V (2011) Experimental and computational approaches to the molecular structure of 3-(2-mercaptopyridine) phthalonitrile. Bull Korean Chem Soc 32: 673-680.

32. Parr RG, Yang W (1984) Density functional approach to the frontier-electron theory of chemical reactivity. J Am Chem Soc 106: 4049-4050.

33. Parr GR, Yang W (1989) Density Functional Theory of Atoms and Molecules. Oxford University Press, New York, USA.

34. Hosseini-Monfared H, Bikas R, Mahboubi-Anarjan P, Blake AJ, Lippolis V et al. (2014) Oxidovanadium (V) complexes containing hydrazone based $O$ N, O-donor ligands: Synthesis, structure, catalytic properties and theoretical calculations. Polyhedron 69: 90-102.

35. Sumrra SH, Ibrahim M, Ambreen S, Imran M, Danish M, et al. (2014) Synthesis Spectral Characterization, and Biological Evaluation of Transition Meta Complexes of Bidentate N, O Donor Schiff Bases. Bioinorg Chem Appl 2014 812924

36. Al-Fulaij OA, El-Sayed AE, El-Asmy AA (2016) $\mathrm{Co}^{2+}, \mathrm{Ni}^{2+}, \mathrm{Cu}^{2+}, \mathrm{Zn}^{2+}, \mathrm{Cd}^{2+}$ and $\mathrm{Hg}^{2+}$ Complexes of Butanedione Hydrazones: Spectroscopic, Thermal and Biological Studies. Am Chem Sci J 13: 1-17.

37. Hamada AM, El-Shishtawi AN, Gomaa AE (2009) Conductometric evaluation of association constants for aqueous solutions of $\mathrm{CoCl}_{2}$ in the absence and presence of a magnetic field. South Braz J Chem 17: 33.

38. Gomaa EA (1987) Solute-solvent interactions of some univalent-univalent salts with various organic solvents at $25^{\circ} \mathrm{C}$. Thermochim Acta 120: 183-190.

39. El-Dossoki FI (2008) Electric conductance and semi-empirical studies on two thiophene derivatives/metal cation complexation. J Mol Liq 142: 53-56.

40. Takeda $Y$ (1983) A conductance study of 18-crown-6 and dibenzo-18-crown-6 complexes with $\mathrm{K}^{+}$in various solvents. Bull Chem Soc Japan 56: 866-868.

41. Atkins WP (1978) Physical Chemistry. Oxford University Press, UK.

42. Ives GJD (1971) Chemical thermodynamics: with special reference to inorganic chemistry. University Chemistry Macdonald Technical and Scientific. 